\title{
ARBUTIN FROM Serratula sogdiana
}

I. L. Zatsny, M. B. Gorovits,

UDC 547.918 and N. K. Abubakirov

Continuing an investigation of Serratula sogdiana Bge. (Compositae) for its content of phytoecdysones [1], from a concentrated methanolic extract of the leaves of this plant we have isolated a crystalline com-

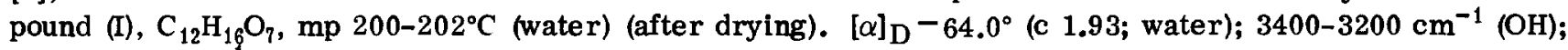
$1235,1085 \mathrm{~cm}^{-1}$ (= C-O-C), 1610, 1595-1515, 840, 815 (benzene ring); mol. wt. 272 (mass spectrometry). The yield on the air-dry raw material was $0.6 \%$.

The acetylation of compound (I) with acetic anhydride in pyridine led to a pentaacetate (II), $\mathrm{C}_{22} \mathrm{H}_{26} \mathrm{O}_{12}$, with $\mathrm{mp} 147-149^{\circ} \mathrm{C}$ (acetone), $[\alpha] \mathrm{D}^{-26.7^{\circ}}$ (c 1.19; acetone).

The hydrolysis of substance (I) with $5 \%$ sulfuric acid gave a sugar which was identified by the GLC method and thin-layer chromatography in silica gel as D-glucose. The aglycone was hydroquinone, $\mathrm{mp}$ $171^{\circ} \mathrm{C}$.

The properties of compound (I) and of its pentaacetate (II) given above enable the glycoside isolated to be identified as arbutin [2]. Arbutin has been obtained previously from other species of Serratula [3].

\section{LITERATURE CITED}

1. I. L. Zatsny, M. B. Gorovits, and N. K. Abubakirov, Khim. Prirodn. Soedin., 840 (1971); 175 (1973).

2. W. Karrer, Konstitution und Vorkommen der Organischen Pflanzenstoffe, Birkhauser Verlag, Basel (1958), p. 88.

3. Ya. K. Yatsyuk, S. S. Lyashenko, and V. S. Batyuk, Khim. Prirodn. Soedin., 54 (1968).

Institute of the Chemistry of Plant Substances, Academy of Sciences of the Uzbek SSR. Translated from Khimiya Prirodnykh Soedinenii, No. 3, pp. 437-438, May-June, 1973. Original article submitted November 27, 1972.

(c) 1975 Plenum Publishing Corporation, 227 West 17th Street, New York, N.Y. 10011. No part of this publication may be reproduced, stored in a retrieval system, or transmitted, in any form or by any means, electronic, mechanical, photocopying, microfilming, recording or otherwise, without written permission of the publisher. A copy of this article is available from the publisher for $\$ 15.00$. 